Please quote as: Söllner, M.; Pavlou, P. \& Leimeister, J. M. (2013): Understanding Trust in IT Artifacts - A new Conceptual Approach. In: Academy of Management Annual Meeting, Orlando, Florida, USA. 
UNDERSTANDING TRUST IN IT ARTIFACTS - A NEW CONCEPTUAL APPROACH

$\underline{\text { Authors }}$

Matthias Söllner, Kassel University, soellner@uni-kassel.de (corresponding author)

Paul Pavlou, Temple University, pavlou@temple.edu

Jan Marco Leimeister, Kassel University \& University of St.Gallen, leimeister@unikassel.de

\section{Acknowledgements}

The information in this document was partly developed through the project VENUS. VENUS is a research cluster at the interdisciplinary Research Center for Information System Design (ITeG) at Kassel University. We thank Hesse's Ministry of Higher Education, Research, and the Arts for funding the project as part of the research funding program "LOEWE - Landes-Offensive zur Entwicklung Wissenschaftlich-ökonomischer Exzellenz”. For further information, please visit: http://www.uni-kassel.de/eecs/en/iteg/venus/

The information in this document was also partly developed through the project Value4Cloud, funded by the German Federal Ministry for Economics and Technology (FKZ: 01MD11043A). 


\title{
UNDERSTANDING TRUST IN IT ARTIFACTS - A NEW CONCEPTUAL APPROACH
}

\begin{abstract}
To add value to companies, IT artifacts - such as information systems - need to be adopted and used. Research and practice have shown that designing IT artifacts in a way that they are readily adopted and used is not trivial. To support designers, research has identified a plethora of factors driving the adoption and use of IT artifacts, with trust being one of the most important factors. Despite this knowledge, research on trust in IT artifact struggles to leverage its potential for IT artifact design, due to several disagreements among scholars. The goal of our paper is to present and reconcile the different competing arguments, and to provide a new conceptual approach to study trust in IT artifacts. The core argument of our approach is that trust is a suitable concept for studying relationships between humans and IT artifact, but trust in an IT artifact should not be studied without examining trust in the provider of the IT artifact. Whereas interpersonal trust theory is suitable to assess trust in the provider of the IT artifact, we propose a new conceptualization for trust in the IT artifact itself. Separately investigating trust in the provider of the IT artifact and trust in the IT artifact itself, will allow researchers to gather a deeper understanding of the nature of trust in IT artifacts and how it can be built. This knowledge will support designers in designing IT artifacts that are more readily adopted and used, and thus can provide the desired value to companies.
\end{abstract}

Keywords: trust, IT artifacts, trust in the IT artifact, trust in the provider of the IT artifact, conceptual paper 


\section{REFERENCES}

Ansari, A., Essegaier, S., \& Kohli, R. 2000. Internet Recommendation Systems. Journal of Marketing Research (JMR), 37(3): 363-375.

Bradley, R., Pratt, R., Byrd, T. A., \& Simmons, L. 2011. The role of enterprise architecture in the quest for it value. MIS Quarterly Executive, 10(2): 73-80.

Davis, F. D. 1989. Perceived Usefulness, Perceived Ease of Use, and User Acceptance of Information Technology. MIS Quarterly, 13(3): 319-340.

Dimoka, A., Pavlou, P. A., \& Davis, F. D. 2011. NeuroIS: The Potential of Cognitive Neuroscience for Information Systems Research. Information Systems Research, 22(4): 687702.

Ebert, T. A. E. 2009. Facets of Trust in Relationships - A Literature Synthesis of Highly Ranked Trust Articles. Journal of Business Market Management, 3(1): 65-84.

Friedman, B., Peter H. Khan, J., \& Howe, D. C. 2000. Trust online. Commun. ACM, 43(12): 3440.

Gefen, D., Karahanna, E., \& Straub, D. W. 2003. Trust and TAM in Online Shopping: An Integrated Model. MIS Quarterly, 27(1): 51-90.

Gefen, D. 2004. What Makes an ERP Implementation Relationship Worthwhile: Linking Trust Mechanisms and ERP Usefulness. Journal of Management Information Systems, 21(1): 263288. 
Gefen, D. \& Straub, D. W. 2004. Consumer trust in B2C e-Commerce and the importance of social presence: experiments in e-Products and e-Services. Omega, 32(6): 407-424.

Gefen, D., Benbasat, I., \& Pavlou, P. A. 2008. A Research Agenda for Trust in Online Environments. Journal of Management Information Systems, 24: 275-286.

ISO/IEC FDIS 25010:2010(E). Systems and software engineering - Systems and software Quality Requirements and Evaluation (SQuaRE) - System and software quality models.

Jarvenpaa, S. L. \& Leidner, D. E. 1999. Communication and Trust in Global Virtual Teams. Organization Science, 10: 791-815.

Jiun-Yin, J., Bisantz, A. M., \& Drury, C. G. 2000. Foundations for an Empirically Determined Scale of Trust in Automated System. International Journal of Cognitive Ergonomics, 4(1): 53.

Kiesler, S. \& Sproull, L. 1997. Social' Human - Computer Interaction. In B. Friedman (Ed.), Human Values and the Design of Computer Technology: 191-199. Stanford, CA: CSLI Publications.

Komiak, S. Y. X. \& Benbasat, I. 2006. The Effects of Personalization and Familiarity on Trust and Adoption of Recommendation Agents. MIS Quarterly, 30(4): 941-960.

Lee, J. \& Moray, N. 1992. Trust, control strategies and allocation of function in human-machine systems. Ergonomics, 35(10): 1243 - 1270.

Lee, J. D. \& See, K. A. 2004. Trust in Automation: Designing for Appropriate Reliance. Human Factors, 46(1): 50-80. 
Lowry, P. B., Vance, A., Moody, G., Beckman, B., \& Read, A. 2008. Explaining and Predicting the Impact of Branding Alliances and Web Site Quality on Initial Consumer Trust of ECommerce Web Sites. Journal of Management Information Systems, 24(4): 199-224.

Luhmann, N. 1979. Trust and power. Chichester, UK: Wiley.

Mayer, R. C., Davis, J. H., \& Schoorman, F. D. 1995. An Integrative Model of Organizational Trust. Academy of Management Review, 20(3): 709-734.

McKnight, D. H., Choudhury, V., \& Kacmar, C. 2002a. Developing and Validating Trust Measures for e-Commerce: An Integrative Typology. Information Systems Research, 13(3): 334-359.

McKnight, D. H., Carter, M., Thatcher, J. B., \& Clay, P. F. 2011. Trust in a Specific Technology: An Investigation of Its Components and Measures. ACM Transactions on Management Information Systems, 2(2): 12:11-12:25.

McKnight, H. D., Choudhury, V., \& Kacmar, C. 2002b. The impact of initial consumer trust on intentions to transact with a web site: a trust building model. The Journal of Strategic Information Systems, 11(3-4): 297-323.

Morgan, R. M. \& Hunt, S. D. 1994. The Commitment-Trust Theory of Relationship Marketing. Journal of Marketing, 58(3): 20.

Muir, B. M. 1994. Trust in automation: Part I. Ergonomics, 37(11): 1905 - 1922.

Muir, B. M. \& Moray, N. 1996. Trust in automation. Part II. Experimental studies of trust and human intervention in a process control simulation. Ergonomics, 39(3): 429 - 460. 
Nass, C., Steuer, J., \& Tauber, E. R. 1994. Computers are social actors, Proceedings of the Conference on Human factors in computing systems (CHI): 72-78. Boston, Massachusetts, United States: ACM.

Pavlou, P. A. \& Dimoka, A. 2006. The Nature and Role of Feedback Text Comments in Online Marketplaces: Implications for Trust Building, Price Premiums, and Seller Differentiation. Information Systems Research, 17(4): 392-414.

Riedl, R., Mohr, P., Kenning, P., Davis, F. D., \& Heekeren, H. 2011. Trusting Humans and Avatars: Behavioral and Neural Evidence. Paper presented at the ICIS 2011 Proceedings.

Rivard, S. \& Lapointe, L. 2012. Information Technology Implementers' Response to User Resistance: Nature and Effects. MIS Quarterly, 36(3): 897-A895.

Singh, J. \& Sirdeshmukh, D. 2000. Agency and trust mechanisms in consumer satisfaction and loyalty judgments. Journal of the Academy of Marketing Science, 28(1): 150-167.

Söllner, M., Hoffmann, A., Hoffmann, H., Wacker, A., \& Leimeister, J. M. 2012. Understanding the Formation of Trust in IT Artifacts, Proceedings of the International Conference on Information Systems (ICIS) 2012. Orlando, Florida, USA.

Sztompka, P. 1999. Trust: A Sociological Theory. Cambridge, UK: Cambridge University Press.

Vance, A., Elie-Dit-Cosaque, C., \& Straub, D. W. 2008. Examining Trust in Information Technology Artifacts: The Effects of System Quality and Culture. Journal of Management Information Systems, 24(4): 73-100.

Venkatesh, V., Morris, M. G., Davis, G. B., \& Davis, F. D. 2003. User Acceptance of Information Technology: Toward a Unified View. MIS Quarterly, 27(3): 425-478. 
Venkatesh, V. \& Bala, H. 2008. Technology Acceptance Model 3 and a Research Agenda on Interventions. Decision Sciences, 39(2): 273-315.

Wang, W. \& Benbasat, I. 2005. Trust in and Adoption of Online Recommendation Agents. Journal of the Association for Information Systems, 6(3): 72-101.

Wang, W. \& Benbasat, I. 2008. Attributions of Trust in Decision Support Technologies: A Study of Recommendation Agents for E-Commerce. Journal of Management Information Systems, 24(4): 249-273. 